\title{
Competenties, wat zijn dat en wat doen we ermee?
}

D. de Bie

\begin{abstract}
Samenvatting
Competenties zijn in de mode, hoewel lang niet duidelijk is wat het begrip competentie precies inhoudt. Achter de invoering van het begrip gaat in ieder geval een pleidooi voor meer beroepsgericht onderwijs schuil, onderwijs dat wordt afgeleid van de te bereiken handelingsbekwaamheid van afgestudeerden. Ook onderwijs dat anders wordt geordend, niet meer in vakken (disciplines), niet meer in kennis los van vaardigheden. Centraal staat het leren van het beroep. Het leren van competenties betekent een andere aanpak van het onderwijs met aandacht voor onder meer beroepsechte opdrachten, opbouw van leerprocessen, leerdynamiek, leerlijnen, samenwerkend leren en anders toetsen. (Bie D de. Competenties, wat zijn dat en wat doen we ermee? Tijdschrift voor Medisch Onderwijs 2002;21(4):161-166.)
\end{abstract}

\section{Inleiding}

Het hoger onderwijs heeft de laatste jaren een verscheidenheid aan onderwijsvernieuwingen voorbij zien trekken. Er was, eind jaren tachtig, modularisering. Daarna kwamen vernieuwingen die het onderwijs studeerbaarder moesten maken, onder meer met hulp van rijksgelden, die onder de titel Kwaliteit en Studeerbaarheid aan onderwijsinstellingen werden toegekend. Vervolgens kwam de roep om zelfstandig leren en het leren leren. Ook de informatie- en communicatietechnologie riep en roept krachtig om vernieuwing. Nu zijn het competenties en competentiegericht onderwijs die aandacht vragen.

De veelheid aan vernieuwingen en het tempo waarin het allemaal plaatsvindt, kunnen makkelijk tot cynisme leiden. Alsof het alleen maar modes betreft, die vanzelf ook wel weer voorbijgaan.

Toch is het te eenvoudig en niet terecht om vernieuwingspogingen simpelweg af te doen als mode of willekeur. Vernieuwingspogingen zijn ook te zien als gegronde kritiek op één of meer aspecten van het bestaande onderwijs. Niet studeerbaar onderwijs wil zeggen een slechte organisatie van het curriculum met weinig oog voor wat nodig is om leerprocessen kwaliteit te geven. En de roep om zelfstandig leren is een aanklacht tegen de veelal schoolse aanpak van het onderwijs, waarin docenten (te) veel voor hun studenten regelen en gedetailleerd vastleggen.

En competenties? De term competentie blijkt vooral verwarring te zaaien. Om welke kritiek het bij competenties gaat, is niet direct duidelijk. Docenten kunnen zich bij 'competenties' weinig voorstellen. Definities en omschrijvingen van het begrip munten niet uit in helderheid. Soms zijn competenties "vermogens", soms zijn het "beroepsvaardigheden" of gaat het om een "brede vaardigheid".1-3 Andere auteurs spreken juist weer van competenties als de "beheersing van vaardigheden". 4 Naast de term competentie duiken regelmatig andere termen op, zoals kwalificatie, kernkwalificatie, sleutelkwalificatie en kernopgave, al dan niet in combinatie met eindterm en beroepsprofiel. Waar gaat het over?

Om helderheid te krijgen, kunnen we twee wegen bewandelen. Onderzoeken 
wat in alle definities en omschrijvingen het bindend element is en vaststellen wat er in het onderwijs anders behoort te zijn als er met competenties wordt gewerkt.

\section{Competenties, wat zijn dat?}

Bij alle definities en omschrijvingen gaat het in de kern om iets wat iemand nodig heeft om het een en ander uit te kunnen voeren. Dat iets wordt door auteurs met verschillende termen benoemd. Het kunnen vermogens zijn, het kunnen beroepsvaardigheden zijn of persoonlijke kenmerken en eigenschappen. Dat iets kan ook met de term bekwaamheid worden aangeduid, of met de term kundigheid en deskundigheid (expertise heet het ook wel). Wie over competenties beschikt, kan iets.

Beroepsopleidingen zijn bedoeld om mensen op te leiden opdat deze mensen, eenmaal afgestudeerd, op verantwoorde wijze beroepswerkzaamheden kunnen uitvoeren, conform de standaarden die daarvoor gelden. Afgestudeerden zijn handelingsbekwaam.

Waarover beschikt die afgestudeerde? Het antwoord levert meestal de bekende reeks op van kennis, inzicht, houding, vaardigheden. Dat verheldert weinig. Belangrijk is dat het om een samenhang gaat. Vaardigheden in het hoger onderwijs staan zelden los van kennis, integendeel.

Het is de vraag of de term competentie de duidelijkheid kan verschaffen die we nodig hebben om studenten op te leiden gaat het eigenlijk niet om een overbodig en modieus begrip?5 Kunnen we niet gewoon spreken van (complexe) beroepsvaardigheden en van beroepsbekwaamheid? We spreken toch ook van een 'proeve van bekwaamheid'?

Van der Maessen en Schakel sommen op wat een competentie in ieder geval niet is:
- niet het gedrag, maar dat wat nodig is om dat gedrag te bewerkstelligen;

- niet eigenschappen en capaciteiten;

- niet aangeboren kenmerken;

- niet de resultaten van het werk;

- niet de motivatie voor het werk. ${ }^{6}$

We houden het erop dat competenties beroepsbekwaamheden zijn, nodig voor het uitvoeren van beroepswerkzaamheden en gekenmerkt door een samenhang van kennis en vaardigheden.

\section{Wat behoort anders te zijn in het onderwijs?}

Met de invoering van het competentiebegrip in het onderwijs wordt de volle aandacht gelegd op het kunnen van studenten. Ook de term beroepsgerichtheid wordt vaak gebruikt. Opleidingen zijn van oudsher gericht op het kennen en weten van studenten.

Tentamens peilen kennis en inzicht, maar wat studenten met kennis en inzicht in de beroepspraktijk kunnen, blijft in tentamens buiten beschouwing. Gaat het in het oude onderwijs veelal om de orthodoxie (het rechte weten), in de praktijk van alledag komt het aan op de orthopraxie (het rechte handelen). Studenten behoren handelingsbekwaamheid te leren en dat betekent kennis, inzicht, vaardigheden, attitudes en alles wat daar verder nog bij hoort. Waar competenties voorop staan, wordt kennis niet verwaarloosd, maar krijgt kennis een zinvoller plaats. Wat is de aard van de kennis die de beroepsbeoefenaar nodig heeft voor het rechte handelen? Gaat het om concrete aanwijzingen voor het handelen, om werkmodellen, of gaat het om achterliggende concepten? ${ }^{7}$ In het eerste geval leert de student de procedures, protocollen, methoden en checklists die voorschrijven en uitleggen wat de student precies te doen staat. In het tweede geval komen de meestal algemene en abstracte 
theorieën aan bod. Het is voor de student belangrijk het verband hiertussen te doorzien. Met behulp van achterliggende theorieën kan het handelen worden verantwoord.

Vervolgens verlangt competentiegericht leren een beroepsgerichte samenhang in het onderwijs. Geen losse delen die de student maar moet zien bijeen te vegen, maar delen die een duidelijke relatie met het te leren beroep hebben. Niet kennis leren los van vaardigheden. Niet een veelheid aan vakken (disciplines) leren los van de beroepscontext.

Het leren van competenties veronderstelt een ander leerproces dan tot nu toe gebruikelijk is. Dat is het essentiële verschil. Grondvraag van nu af aan is 'hoe leert iemand dit beroep' en dat is de vraag naar de beroepsdidactiek.

\section{Een competentiegericht curriculum}

Het leren van competenties verlangt niet alleen andere leerstof (of anders geordende leerstof), maar ook andere leerprocessen.

\section{Beroepsechte opdrachten}

Stel dat er geen opleiding zou bestaan, hoe zouden studenten het beroep leren? Het ligt voor de hand dat het er anders aan toe zou gaan dan nu meestal het geval is. Studenten zouden zich oriënteren door een tijdje met iemand mee te lopen, zouden een opdracht krijgen om bepaalde observaties uit te voeren, zouden wellicht hier en daar eenvoudige handelingen verrichten. Het leren van het beroep betekent niets anders dan zo snel mogelijk de competenties leren. Dat wil zeggen een geïntegreerde leerlijn.

In de medische beroepsopleiding worden onderzoeken, diagnosticeren en adviseren zoveel mogelijk geïntegreerd geleerd. Het beroep wordt de opleiding binnengehaald. Studenten voeren als het ware beroepswerkzaamheden uit. Docenten geven studenten werkopdrachten en zorgen er vervolgens voor dat er van de uitvoering geleerd kan worden.

Zo'n aanpak doet denken aan het gildenwezen, waarin de meester de gezel hielp om al doende het vak te leren. De meester gaf opdrachten en aanwijzingen, besprak de resultaten en bemoedigde waar nodig. Het is opmerkelijk hoe vaak in de competentieliteratuur een verwijzing naar dat gildensysteem opduikt. De kern is steeds: leer een beroep door de complexe taken van dat beroep aan de student voor te leggen, dat wil zeggen een 'whole task' benadering. ${ }^{8}$ Dat is uiteraard op papier makkelijker geschreven dan in de praktijk gedaan, want het betekent een ingrijpende breuk met de bestaande ordeningen van de leerstof. Competentiegericht leren vraagt echter om meer.

\section{Concentrisch leren}

In het bestaande onderwijs werken studenten de onderdelen na elkaar af. De oude leerstof wordt, nadat het tentamen gehaald is, grotendeels vergeten. De docent die in een tentamen vragen opneemt over leerstof van een vorig tentamen kan rekenen op protest van studenten, mogelijkerwijs zelfs een beroep bij de examencommissie. Het leren van competenties betekent evenwel niet het verwerken van losse onderdelen, maar het steeds meer greep krijgen op competenties. Er vindt verbreding plaats, verdieping, verrijking, dat wil zeggen dat het leren van competenties een doorgaande ontwikkeling en uitbreiding is van kennis, inzicht en vaardigheden.

\section{Leerdynamiek}

Het voorleggen aan studenten van opdrachten die ontleend zijn aan het beroep biedt de kans om leerdynamiek te bewerkstelligen. Leerdynamiek wil zeggen 
leerprocessen waarin studenten intensief en energiek de activiteiten uitvoeren en waarin diepgaand wordt geleerd. Er is nieuwsgierigheid, motivatie, inzet, en studenten zijn bereid om de voorgelegde opdrachten nauwgezet uit te voeren.

Beroepsechte opdrachten prikkelen de student. Het is de bekwaamheid van de docent om dergelijke opdrachten te construeren en daarmee leerdynamiek te bewerkstelligen. Het gaat om het oproepen van ambitie bij studenten. Immers, wie niet wil leren, leert weinig of niets. Docenten die met projectopdrachten hebben gewerkt in hun onderwijs weten dat het bovenstaande meer is dan fraaie taal. Leerdynamiek bevordert de motivatie. Motivatie is niet een vast gegeven, maar is veranderlijk, is te vergroten of te verkleinen. Inspirerende, uitdagende opdrachten kunnen leerdynamiek bewerkstelligen.

\section{Opdrachten}

Opdrachten vormen het hart van het leerproces. Opdrachten maken duidelijk wie wat doet, opdrachten maken ook verantwoordelijkheden zichtbaar. De docent construeert goede, zinvolle opdrachten, de student voert deze opdrachten uit, en beiden kunnen elkaar daarop aanspreken. Opdrachten maken studenten verantwoordelijk voor het leerproces.

Onderwijsvormen en werkvormen zijn afgeleiden van opdrachten. Projectonderwijs en probleemgestuurd onderwijs staan of vallen met de kwaliteit van de opdrachten. Hoorcolleges, werkgroepen en practica zijn allemaal afhankelijk van opdrachten.

De docent construeert opdrachten, legt deze aan studenten voor en helpt studenten vervolgens om van het uitvoeren van opdrachten te leren. ${ }^{9}$

\section{Leerlijnen}

Studenten verwerven competenties door zo realistisch mogelijk te oefenen. Toch is dat lang niet altijd direct mogelijk. Naast de geïntegreerde leerlijn waarin studenten beroepsechte opdrachten uitvoeren, zijn andere leerlijnen nodig en mogelijk: de conceptuele leerlijn, de vaardigheidsleerlijn, de ervarings-reflectieleerlijn. Maar deze leerlijnen zijn wel consequent afgeleid van competenties die in een leerplanschema overzichtelijk zijn geordend en vastgelegd. Daardoor kan in iedere leerlijn ook leerdynamiek worden opgeroepen.

In de conceptuele leerlijn leren studenten professioneel denken en redeneren. De docent treedt op als het voorbeeld van een professional die laat zien (en horen) hoe een professional denkt en redeneert en die studenten opdrachten geeft ook dergelijke denkprocessen uit te voeren.

In de vaardigheidsleerlijn merken studenten dat ze steeds vaardiger en handiger worden, dat zij de skills van het vak steeds beter beheersen en dat zorgt voor leerdynamiek. De vaardigheden staan niet los van competenties, zodat het niet gaat om trucs.

De ervarings-reflectieleerlijn is in stages geplaatst en studenten merken dat het werken steeds beter gaat. De dynamiek van deze leerlijn is gelegen in de wil om het 'morgen beter te doen'. Stages vormen een belangrijk onderdeel van het competentieleren.

Het is zaak de leerlijnen consequent te onderscheiden om daarmee te voorkomen dat de leerdynamiek wordt verstoord.

\section{Toenemende integratie}

Er mogen verschillende leerlijnen zijn, in het curriculum zal de geïntegreerde leerlijn steeds meer leertijd in beslag gaan nemen. Wat eerder in de conceptuele leerlijn en in de vaardigheidsleerlijn werd ge- 
leerd, wordt later in de opleiding verbreed en verdiept in de geïntegreerde leerlijn. In het laatste studiejaar kan de geïntegreerde leerlijn wellicht honderd procent van de studietijd in beslag nemen. Dat wil niet zeggen dat er dan geen nieuwe concepten worden geleerd en geen nieuwe vaardigheden worden geoefend, maar dat dit leren is ingebed in het verwerven van de competenties, bijvoorbeeld door middel van onderwijs dat op grond van vragen van studenten wordt uitgevoerd.

\section{Samenwerkend leren}

Waar de beroepspraktijk voorop staat, zal het geen verbazing wekken dat het leren van competenties ook betekent dat veelvuldig samenwerkend wordt geleerd. Werken in teams is een vanzelfsprekend onderdeel van vrijwel alle toekomstige arbeid. Bovendien biedt samenwerkend leren didactisch interessante mogelijkheden. Studenten leggen elkaar concepten uit, doen vaardigheden voor, beoordelen elkaar. Studenten voeren bijvoorbeeld binnen projecten individuele opdrachten uit en worden op de uitvoering door hun collega-studenten aangesproken.

\section{Zelfstandigheid}

Beroepsechte opdrachten roepen leerdynamiek op, maar er is nog een ander belangrijk ingrediënt voor die leerdynamiek: zelfstandigheid. De opdrachten roepen zelfstandigheid op, zij het binnen de grenzen die de opdracht stelt. Grenzen als: in te leveren plan-van-aanpak, einddatum en dergelijke. Het zijn grenzen die gebruikelijk zijn in het arbeidsleven en die vrijblijvendheid voorkomen.

$\mathrm{Nu}$ zijn studenten bij binnenkomst in het hoger onderwijs niet allemaal toe aan een grote mate van zelfstandigheid, het ontbreekt velen aan (leer)vaardigheden als plannen, samenwerken, communice- ren, reflecteren, feedback geven, toetsen, beoordelen. In het curriculum wordt aangegeven op welk moment deze algemene vaardigheden worden geleerd, opdat zo snel mogelijk de zelfstandigheid kan worden opgevoerd.

\section{Toetsen}

Alle pogingen om leerdynamiek tot stand te brengen zullen falen als het toetsen en beoordelen op de oude wijze wordt voortgezet, dus met de beruchte kennistentamens, met de vele herkansingen, met de tentamenweken. Het toetsen vraagt om een ingrijpende herwaardering in competentiegericht onderwijs. Competenties worden niet in één keer geleerd en het toetsen is vooral bedoeld om de student te helpen het leerproces goed te vervolgen. Het gaat niet om zakken of slagen, maar om 'hoever is de student'. Studenten leren zelf resultaten te toetsen en te beoordelen en de docent stelt vast of dat toetsen en beoordelen de toets der kritiek kan doorstaan (meta-beoordelaar).

\section{Consequenties van competenties}

Consequent werken met competenties in het onderwijs zal al met al ingrijpende veranderingen teweegbrengen. Het curriculum wordt anders ingedeeld en opgebouwd op basis van de te ontwikkelen beroepsdidactiek. Ook docenten hebben competenties nodig om hun werk goed uit te kunnen voeren en het leren daarvan is meer en anders dan het volgen van wat cursussen. Dat vraagt evenzeer om competentiegericht leren. Ons onderwijs consequent inrichten op basis van competenties is niet eenvoudig. Het vraagt zorgvuldigheid, vindingrijkheid, geduld en behoorlijk wat ambitie. De conclusie is niet te vermijden: Competenties? Daar zijn we nog niet klaar mee! 


\section{Literatuur}

1. Onstenk J. Lerend leren werken. Delft: Uitgeverij Eburon; 1997, p. 92.

2. Klarus R. Competenties erkennen. 's-Hertogenbosch: CINOP; 1998, p. 40.

3. Buskermolen F, Parra B de la, Slotman R, redactie. Het belang van competenties in organisaties. Utrecht: Uitgeverij Lemma; 1999. p. 25.

4. Evers FT, Rush JC, Berdrow I. The bases of competence. San Fancisco; Jossey-Bass Publishers; 1998. p. 25.

5. Bie D de, Mostert P. Competentie, over de overbodigheid van een modieus begrip. Onderzoek van Onderwijs 2000, 29(2):20-3.

6. Maessen PEAM van der, Schakel L. Wat zijn competenties niet? Opleiding en Ontwikkeling 1999;12:11-7.
7. Bie D de, Kleijn J de. Wat gaan we doen? Houten: Bohn Stafleu Van Loghum; 2001.

8. Janssen-Noordman A, Merriënboer $\mathbf{J}$ van, Vleuten $\mathrm{C}$ van der, Bouhuijs P. Het leren van complexe taken. Onderzoek van Onderwijs 2000,29(3): 37-41.

9. Bie D de, Gerritse J. Onderwijs als opdracht. Houten: Bohn Stafleu Van Loghum; 1999.

De auteur:

Drs. D. de Bie is partner van de BDF Adviesgroep te Maurik.

Correspondentieadres:

Drs. D. de Bie, St. Nicolaaslaan 38, 3984 JB Odijk, tel + fax0306562020,bdfdebie@worldonline.nl of ddb@bdfadvies.nl. Homepage:www.bdfadvies.nl.

\section{Summary}

Competencies are a fashionable, albeit rather vague, notion. The introduction of the concept of competencies signifies a plea for education aimed at training competent professionals, with orthopraxis taking precedence over orthodoxy. The student should learn a profession, not a sequence of separate discipline-related subjects, not skills without knowledge. The focus of education should be what and how a student should learn to become a professional. If students are to learn competencies we need to offer them an appropriate new curriculum characterised by realistic assignments in a work-related context, cyclical learning, learning dynamics, learning tracks, cooperative learning and other assessment modes. (Bie D de. Competencies: what are they and how to use them? Dutch Journal of Medical Education 2002;21(4):161-166.) 